\title{
The Meaning of Debt at the Rambu Solo' Funeral Ceremony
}

\author{
Luther P. Tangdialla ${ }^{1}$, Erna Pasanda ${ }^{2}$, Randi Tangdialla ${ }^{3}$ \\ Indonesian Christian University of Paulus ${ }^{1,2}$, Indonesian Christian University Toraja ${ }^{3}$ \\ \{luthertangdialla@gmail.com $\left.{ }^{1}\right\}$
}

\begin{abstract}
The purpose of this study is to reveal the meaning of debt at the funeral ceremony of rambu solo' in the life of the Toraja society. The implementation of traditions and culture through a rambu solo' funeral ceremony is requires a lot of energy and assets. Assets that are usually sacrificed in a funeral ceremony rambu solo' are buffalo and pigs. Buffalo and pigs are animals that have the highest value if compared to other animals in the Toraja community. The assets sacrificed at the rambu solo' funeral ceremony does not only belong to the family of the person being celebrated, but also comes from extended family and close relatives, which is in the form of assistance. Although this assistance can be considered as debt, but in Toraja society, this debt has its own meaning and is different from the meaning of debt known in accounting. This study uses a qualitative method with a phenomenological approach. The data was collected through interviews with 4 informants and at the same time direct observation was carried out in the funeral ceremony of rambu solo '. The results of the study found 3 (three) meanings of debt in the funeral ceremony of rambu solo ', namely : attention, togetherness and care
\end{abstract}

Keywords : Toraja culture; rambu solo'; debt

\section{Introduction}

Debt is one of the important topics studied in various financial accounting literatures and accounting audits. This is because debt is one of the sources of funding for an entity in managing its business. Therefore debt is a common thing in the business management . Every company's financial statement must have a debt account. Debt is not always considered that the company is experiencing financial difficulties, but debt is needed to maintain financial turnover in the business process, provided that the asset value must be greater than debt. To arrange for debt payments not to be concurrent, based on the timing there are two types of debt in accounting, namely short-term debt and long-term debt. Debt is an economic sacrifice for the future in the form of submission of services, assets, as part of a past transaction or agreement between the two parties. Recognition of debt is not only in the form of cash, but also securities, bonds, stocks, debt instruments and so on. If used for productive purposes, debt will be able to provide benefits to the entity 
According to the Statement of Financial Accounting Standards (Indonesian Institute of Accountants, 2015: 9, 11 in Agoes 2019: 16) that liabilities are current corporate debt arising from past events, the settlement is expected to result in an outflow of company resources that contain economic benefits. This study aims to reveal another perspective of business organizations, namely looking at the perspective of tradition and culture to reveal the meaning of debt in the funeral rambu solo' not in the context of financial transactions or past agreements as used in accounting.

As part of social science, accounting has a strong interaction (mutual influence) with the social environment of society so that it has a role in shaping the reality of society (Hines 1988, Morgen 1988, Triyuwono 2012 in Tumirin 2015). Society has the characteristics of a complex and different social environment so that it is possible for them to have different perspectives on an object including the accounting concept (Ahmed 1994 in Tumirin 2015).

The Toraja tribe is one of the tribes in South Sulawesi who maintains its traditions and culture. They live and settle in the mountains of the northern part of South Sulawesi and the surrounding areas, namely in the plains of Luwu and West Sulawesi. The Toraja people who live in mountainous areas are still preserving their traditions and culture that were inherited from their ancestors from generation to generation. Although it has been through a process and cultural assimilation, nowadays you can find Protestant Christianity, Catholicism and Islam, but rituals with old beliefs (aluk todolo) still dominate every rambu solo' funeral ceremony in their lives. Toraja is known as Tondok Lepongan Bulan Tana Matari' Allo which means a country that is round like the moon and the sun is known to the world for its rich traditions and unique culture. One of the traditions and culture that the Toraja people continue to maintain until now is the implementation of a funeral ceremony rambu solo'. It is this activity that triggers debt, which is arises in every funeral ceremony held by the Toraja people.

This funeral ceremony is carried out by observing the social class of the deceased. In the implementation of the funeral ceremony for the rambu solo' for the upper middle social class, it is usually carried out very festively, which means that from the implementation of the rambu solo' activities, a large amount of debt will arise for the family, children and grandchildren of the deceased. One of the elements that measure the excitement and greatness of rambu solo' funeral ceremony can be seen from the amount of buffalo and pigs slaughtered during the activity. Although the rambu solo' funeral ceremony requires a large amount of assets, in the understanding of the Toraja people the amount of assets expended during the implementation of the activity is not proportional to the services and kindness of the person they love while they are still alive.

The funeral ceremony of rambu solo' is actually a ritual that cannot be separated from the old belief (aluk Todolo). In addition to being interpreted as the final tribute to a loved one who has died, it is also inseparable from the meaning of the symbols in the process and stages of implementing the rambu solo' ceremony. This symbol can be in the form of prayers said by To Minaa which means glorification, worship and supplication. Other symbols can also be in the form of ceremonial equipment which means an offering to the ancestors and is the last tribute to the deceased from all family, relatives and to ma'rapu (extended family community). In its implementation, the funeral rambu solo' is bound by a rule called aluk. The old belief of the Toraja people believes that aluk was created in the sky. Therefore, aluk is divine and all creatures are subject to aluk (Sarira, 1996: 63 in Pasulu et al : 2019).

In this research, the writer will describe the meaning of rambu solo' and the types of rambu solo' funeral ceremony' and the meaning of debt in the frame of Toraja tradition and culture. 
According to Tangdilintin (in Pasulu, et al 2019), the term of aluk rambu solo' is built from three words, namely aluk (belief), rambu (smoke or rays), and solo' (down). Therefore aluk rambu solo' can be interpreted as a ceremony which is held on the day it begins goes down. The stages in the implementation of the rambu solo' ceremony are an event that contains religious and social dimensions (Duli \& Hasanuddin, 2003: 2008 in Pasulu at al 2019). The point of this statement is that the implementation of the funeral rambu solo' cannot be separated from the old belief of the Toraja people (aluk todolo) who believe that the spirits of the deceased will go to puya (world of the dead). The happiness of the dead who have been in the puya depends very much on how many livestock (buffalo and pigs) are slaughtered during the funeral ceremony of rambu solo'

In Toraja culture, there are four kinds of social levels or strata, among others : 1). Tana' bulaan or upper aristocratic class, 2). Tana' bassi or middle class, 3). Tana' karurung or ordinary people (free people), 4). Tana' kua- kua or group of servants (Duli \& Hasanuddin, 2003: 28 in Pasulu at al 2019). This social group is an order that regulates the behavior of group members, including giving distinctive characteristics in carrying out the rambu solo' ceremony '(Duli \& Hasanuddin, 2003: 28 in Pasulu et al 2019).

The social level or strata in the Toraja tradition and culture causes the funeral ceremony for everyone who dies is not always the same or different. Apart from factors of social strata, these differences are also caused and influenced by the economic capacity of the family of the person being proposed. The funeral ceremony has the highest symbolic meaning, which is interpreted as the provision of an abundant offering of buffalo sacrifices, amounting to at least 24 tails known as the Sapu Randanan Funeral Ceremony (Sitonda, 2007: 65)

\section{Methodology}

This study aims to reveal and determine the meaning of debt arising from implementation of the rambu solo' funeral ceremony among the Toraja people. In line with the objectives to be achieved, the method used in this study is a qualitative method with a phenomenological approach, namely through observation and interviews. A qualitative research method with a phenomenological approach is research that seeks to uncover and describe a phenomenon about experience from the point of view of the research subject or informant. One of the advantages of phenomenological studies is its ability to uncover experiences hidden in the philosophical and psychological informants through descriptive narratives so that readers and researchers can understand the life experiences experienced by the research subjects.

Research that uses a qualitative method with a phenomenological approach seeks to reveal the personal experience of the informants into a universal meaning of a phenomenon experienced by a group of individuals. In this study, the personal experiences of each informant will be collected to find the same meaning. According to Moleong (2015: 6) qualitative research is research that intends to understand the phenomena experienced by research subjects such as perceptual behavior, motivation, actions and others holistically and by means of descriptions in the form of words and language in a context. special nature and by making use of various scientific methods. Therefore the use of qualitative methods with a phenomenological approach is expected to reveal the meaning of debt at the rambu solo' funeral ceremony.

\section{Results and Discussion}


This study took data from 4 (four) informants. They are generally people who are directly involved and have experienced and carried out several times a funeral ceremony of rambu solo '. The data collection methods used in this study were observation and interviews. The interview technique used was in-depth unstructured interviews. Hanurawan (2016, in Pambudi, 2017) explains the types of in-depth unstructured or informal interviews are interviews that are spontaneous and very unstructured. In the implementation of this interview process, the interviewer and the subject conduct a discussion on a topic which is then followed by an in-depth study of the issues that arise around the topic. The results of the meaning of debt obtained by researchers can be grouped into 3 (three) meanings which at the same time underlie why large families or relatives in Toraja society feel they have an obligation to take part in every implementation of the rambu solo' funeral ceremony. The three meanings are : a) attention, b) togetherness c) care. The Toraja people believe that large works can be completed if they are carried out in mutual cooperation. The concept and rationale are what become the reference for the Toraja people so that wherever they are, the characteristics of being a Toraja are always visible, especially if a family or relative has died. Family and close relatives feel ashamed to attend every rambu solo' funeral ceremony if they do not take part or do not participate in providing assistance by bringing buffalo or pigs. This buffalo or pigs will be returned within an unspecified time limit because it depends on the implementation of the rambu solo' ceremony which is carried out by the person concerned in the future. The payback period can be less than one year, one year or even dozens of years. This assistance is what can be referred to as debt in economic or accounting terms, but in the context of Toraja tradition and culture, according to the results of this study it is interpreted as attention, togetherness and care. The meaning of debt in the funeral ceremony of rambu solo' is emphasized in the quote from Mr. Agustinus's interview below

"Debt in the context of Toraja tradition and culture cannot be equated with debt in the sense of debt in general because the debt is not planned and the process occurs spontaneously with a rambu solo' party". We cannot prohibit family or relatives from carrying buffalo or pigs because they do not want to attend the funeral ceremony if it is prohibited to bring buffalo or pigs. This customary and cultural debt is basically based on mutual concern and as a form of concern for the family who carries out the funeral ceremony for rambu solo'. In this kind of debt, it is not determined when the buffalo or pigs will be returned, maybe a week, a month or years, depending on the funeral rambu solo' which is carried out by those who bring the buffalo and pigs. So the debt in the custom and culture of Toraja is more dominated by brotherhood, togetherness and care that are within the framework of preserving Toraja custom and culture"

This excerpt from the interview with Augustine has a deep meaning, where debt is interpreted as brotherhood, togetherness and care. Mr. Agustinus does not see the debt arising from the funeral ceremony of rambu solo' as a heavy burden that must be borne by the family, but instead is seen as something normal when viewed from the side of custom and culture and interpreted as a relationship of brotherhood, togetherness and care.

Another meaning of debt in the funeral ceremony of rambu solo' through an interview with one of the Toraja community figure, Mr. Onesimus: "Many people say that funeral ceremony of rambu solo' in Toraja custom and culture is consumptive behaviour. But in my opinion, the real meaning of the rambu solo' funeral ceremony is as a form of affection and gratitude for the deceased. And through the funeral ceremony that is carried out it will give our own satisfaction because we feel we have carried out our responsibility as Toraja people. And if the family and relatives who are present do not bring buffalo and pigs, the funeral will lose its meaning. The rambu solo' funeral ceremony is also an opportunity to gather families 
who live far from Toraja, it is also an opportunity to help each other and an opportunity to be together and care for each other in dire circumstances". As an illustration, my friend had brought me a buffalo when my grandmother died, and a few years later my friend's in-laws died and I brought a buffalo which was smaller in size and my friend didn't mind.

The excerpt from the interview with Mr. Onesimus is not much different from the excerpt from the interview with Mr. Agustinus, who in general sees the meaning of debt as a form of mutual help and as a form of togetherness without paying attention to the value of the buffalo or pig that was brought in the funeral ceremony of rambu solo'

The condition felt by Mr. Agustinus and Mr. Onesimus was also felt by Mr. Yohanis Patimang. The following is an excerpt from an interview with Mr. Yohanis Patimang: "Debt in Toraja custom and culture, especially in the funeral ceremony of rambu solo' is a manifestation of the act of loving and giving mutual attention, the important thing is not to do it excessively so that the rambu solo' funeral ceremony which is carried out does not go out of its true meaning, namely preserving Toraja tradition and culture. . Because if the assistance provided by family and relatives is excessive, it will have a negative impact on the future of the person being assisted from generation to generation, namely that they will live a life that is never free from the burden of debt".

The excerpt of the last interview with Mr. Suri Pappa is as follows: "Talking about debt in rambu solo' funeral ceremony is a form of high concern from close family and close friends because they share the circumstances or events experienced by the bereaved family. The form of attention given is manifested by giving buffalo or pigs to be used in the implementation of the funeral rambu solo'.

The excerpt from the interview with Mr. Suri Pappa illustrates that the assistance provided by extended family and friends is interpreted as a form of high attention

\section{Conclusion}

The rambu solo' funeral ceremony is one of the Toraja traditions and culture that is still maintained and maintained by the Toraja people until now. The rambu solo' funeral ceremony is full of meaning and has been integrated into the life of the Toraja people. In the rambu solo' funeral ceremony, the number of animals in the form of buffaloes and pigs that are slaughtered as sacrifices is influenced by the social status of the deceased. The social status of the aristocratic class (tana' bulaan) required the slaughter of buffalo and pigs which were more than the lower social status. This condition causes the Toraja people who carry out the rambu solo' funeral ceremony spontaneously to receive help from extended family and close friends who cannot be rejected but must be accepted as a form of mutual concern, mutual respect, and mutual care.

Assistance in the form of buffalo and pigs is what in general and accounting terms can be interpreted as debt, however by the Toraja people it is interpreted as a form of attention, togetherness and care. If some day each person concerned also carries out a rambu solo' funeral ceremony, then there is an opportunity to do the same thing, namely giving a buffalo or a pig but the size of the buffalo or pig given does not have to be the same as the aid received before, but may be of a larger size. small or bigger depending on ability.

\section{References}


[1] Agoes, Sukrisno. 2017. "Auditing". Buku 2, edisi 5 Jakarta: Empat Salemba

[2] Aditjondro, George J. 2010. "Pragmatisme Menjadi Sugi' dan Kapua di Toraj". Yokyakarta: Sopai Press

[3] Bigalke, Terance W. 1981. “A Social History of Tana Toraja 1870-1965. Ph.D dissertation Departement of History. University of Wisconsin, Madison

[4] Crystal, Eric. 1974. " Cooking Pot Politics ". A Toraja Village Study. Indonesia 18 : 119-147

[5] Embon, Debyani, dan I Gusti Ketut Alit Saputra. 2018. "Sistem Simbol dalam Upacara Adat Toraja Rambu Solo': "Studi Semiotik". Jurnal Bahasa dan Sastra, Volume 3. No. 7

[6] Endraswara, Suwardi. 2012. "Metodologi Penelitian Kebudayaan". Yokyakarta: Gadjah Mada University Press

[7] Keynes, Charles F. 1981. Ethnic Change . Seattle : University of Washington Press

[8] Geertz, Clifford . 1973. " The Interpretation of Cultures ”. New York : Basic Books

[9] Kuswarno, E. 2009. "Fenomenologi". Bandung: Widya Padjadjaran

[10] Moleong, J. Lexy. 2010. "Metode Penelitian Kualitatif". Bandung: PT. Remaja Rosdakarya

[11] Moeryadi, D. 2009. "Pemikiran Fenomenologi Menurut Edmund Husserl”. Diterbitkan Oleh Journa of Blogspot Studies

[12] Mulyana, Dedy. 2013. "Metodologi Penelitian Kualitatif : Paradigma Baru Ilmu Komunikasi dan Ilmu Sosial Lainnya" Bandung: PT. Remaja Rosdakarya

[13] Pasulu, Helma Yances, Rama Tulus Pilakoannu, dan Izak Y.M. Lattu. 2009. "Dilema Identitas Dalam Pelaksanaan Ma'pasilaga Tedong Dalam Rangkaian Ritual Rambu Solo' ". Jurnal Humaniora Yayasan Bina Darma Volume VI No.1

[14] Pambudi, Kukuh Setyo, dan Indah Yasminum Suhanti. 2017. "Studi Kasus Penelitian Fenomenologi Persepsi Keadilan Pelaku Keadilan PKI 1965", Jurnal Sains Psikologi, Volume 6. No. 1

[15] Paranoan, Natalia and Erna Pasanda. 2017. "Power Behind Pricing Practices Based Torajanese Culture". Research Journal of Finance Accounting Vol.8 No.6

[16] Sugiyono. 2012. "Pengertian Riset Kualitatif" . Bandung : CV. Alfabeta

[17] Santana, S. 2010. "Metode Penulisan Penelitian Kualitatif Ilmiah" Jakarta : Yayasan Pustaka Obor Indonesia

[18] Sitonda, Mohammad Natsir. 2007. "Toraja Warisan Dunia". Makassar : Refleksi

[19] Tumirin, dan Ahim Abdurahim. 2015. "Makna Biaya Dalam Upacara Rambu Solo". Jurnal Multiparadigma Akuntansi, Volume 6 No.2 